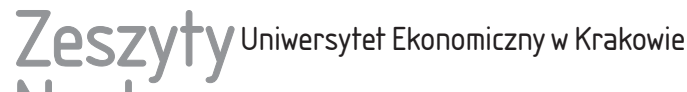 Naukowe
}

\section{The Impact of European Funds on Public Expenditure in Poland}

\begin{abstract}
The main purpose of the study is to evaluate the impact of European funds on the level and structure of public expenditure in Poland. Basically, the research period covers the years 2000-2016. In pursuit of objectivity, the following hypothesis is put forth: EU funding has a significant impact on the amount and structure of public expenditure.

The analysis of data on the amount of European funds supporting the state budget in Poland proves that the share of these funds in the financing of public tasks is high and the structure of public expenditures is significantly changed. In the period 20102015 these funds accounted for about $88 \%$ of public expenditure. It is clear that they have systematically, if gradually, risen. Over the period 2014-2015, funding exceeded $90 \%$ of total expenditure.
\end{abstract}

Keywords: European funds, operational programme, the EU funds budget, public expenditure.

JEL Classification: H50, H60.

\section{Introduction}

Poland's long presence in the EU has yielded measurable benefits. They are evidenced not only by the results of analyses on the development of macroeconomic indicators, but above all by public opinion. The latest data show that for over two years the percentage of supporters of Poland's membership in the European Community has not fallen below $80 \%$. According to CBOS, the majority 
are supporters in all socio-demographic groups (Polska w Unii Europejskiej... 2016, p. 2). Furthermore, the Supreme Chamber of Control (NIK), referring to estimates by the Ministry of Infrastructure and Development, notes that around $20 \%$ of Poland's average annual GDP growth is the result of the implementation of investments co-financed by EU funds (Analiza... 2014, p. 198). Public expenditure is one channel by which EU funds are transmitted to the country's economy.

The main purpose of the study is to assess the impact of European funds on the level and structure of public expenditure in Poland. The study answers the following research questions: Did the EU funds impact the amount and structure of public expenditures in Poland? What is the direction of changes in funding by EU funds? Can the changes to public expenditures be assessed as beneficial? The subject of the study is public expenditure in Poland in the period 2000-2016. Its main hypothesis is that EU funding has a significant and positive impact on the amount and structure of public expenditure in Poland.

The paper is organised as follows. Chapter one presents a review of the literature. The second chapter outlines the concept and structure of funding for EU policies based on financial perspectives. This chapter also shows the financial flows from the EU budget funds received by Poland.

The third chapter discusses the directions for implementation of national public policies that reflect expenditure for the implementation of operational programmes. The fourth chapter presents an analysis of expenditure by economic groups, including expenditure on financing and co-financing of projects involving EU funds.

\section{Literature Review}

In the subject literature, the factors that determine the level of public expenditures are interpreted in a variety of ways. It is noteworthy that the level and structure of public expenditures are influenced by historical conditions as well as the socio-economic doctrine taken by the public authorities (Owsiak 2017). A. Kasperowicz-Stępien (2011) sees both the level and structure of expenditures as a problem, the solution to which is often a compromise between different options and arguments. A. Moździerz (2009), in turn, emphasises systemic changes. Looking at the structure of expenditures, the author argues that the change in the rules of recognising expenditures for the implementation of programmes and projects within the structural funds and in-community initiatives (which were included in the state budget in 2006) caused an increase in legally determined expenditures. As of 2010, the budget of European funds has been excluded from the state budget. In accordance with the economic approach of expenditures, the 
state budget included the contribution to the EU budget as well as the amounts related to the co-financing of EU projects. Such an approach has left some with an opinion of EU funds, which tighten up state budgets with their already high share of legally determined expenditures.

At the same time, EU funds are considered crucial to the economic, social and administrative development of Central and Eastern European countries (Klimowicz 2010). The use of European funds brings about numerous benefits, which are viewed as incentives to making new investments in both the public and private sectors. M. Tomova et al. (2013) showed that European funds help Member States improve their socio-economic development, particularly when it is linked with solid domestic fiscal and macroeconomic policies. P. Wostner and S. Šlander (2009) confirmed that cohesion policy effectively increases Member States' structural expenditures, fulfilling one of the conditions essential for the effectiveness of EU transfers. O. Podlińska and J. Gołębiewski (2013) also conducted research concerning the impact of European funds on the expenditure level. Their research examined the impact of EU support schemes on municipal investment expenditures, and established that investment expenditures increased after Poland's accession to the EU. Their analysis of the share of EU funds in investment expenditures indicates that the municipalities showed greater activity and effectiveness in obtaining EU funds in the first years of membership. However, A. P. Czepiel (2016) has emphasised that while the efficiency of spending funds is thought important, little is known about it. The author suggests that the reason for this is the underdeveloped assessment systems indicating the impact of European funds - at national, local and regional levels in Poland - on economic growth.

To the best of my knowledge, empirical studies on the influence UE funds have on the extent and structure of public expenditure according to economic groups in Poland is poor. This study addresses both of these areas. The subject literature has most often dealt with public finances in general (Sawulski 2016), the possibilities of financing investments within particular EU programmes, the influence of EU funds on employment, economic growth and the development of the country and its regions (Sosinska-Wit 2014). The literature also illustrates the difficulties that exist in measuring the efficiency and effectiveness of public spending (Mandl, Dierx \& Ilzkovitz 2008).

\section{The Limits and Directions of Funding Defined by the Multi-annual Financial Framework}

Data from the European Commission (www.ec.europa.eu, accessed: 25.01.2017) show that expenditure on implementing the common agricultural 
policy was predominant in the structure of expenditure of the EU general budget between the years 2000-2006 (48\% on average per annum). These were, among others, expenditure on direct subsidies for agricultural production and subsidies for exports of agricultural products to third countries. The second most significant group involved structural funds (31\% on average). 2007 marks the introduction of a new breakdown of expenditures adjusted to the priorities defined for this period. The new main lines of financing are to provide sustained economic growth, with over $41 \%$ of total funds being allocated annually and natural resources management (45\%). It is important that, over the period 2007-2011, expenditure on the conservation of natural resources, i.e. agriculture, rural development, environment and fisheries, outweighed the costs of sustainable economic growth. It was only in 2012-2013 that the relationship changed in favour of economic expenditures. In the financial perspective for 2014-2020, the structure of the financial framework is similar. There are still two main areas to be financed, i.e. economic development and natural resources. Over $47 \%$ of the annual average is transferred under EU funds for economic purposes, and in the latter case it is close to $40 \%$ (www.ec.europa.eu/budget, accessed: 25.01.2017, Multiannual Financial Framework... 2013, p. 8). Table 1 presents details of the main EU funding areas.

Table 1. EU Funding Areas for 2000-2015 (Billion EUR)

\begin{tabular}{|c|c|c|c|c|c|c|c|}
\hline Specification & 2000 & 2001 & 2002 & 2003 & 2004 & 2005 & 2006 \\
\hline Common agricultural policy & 40.5 & 41.5 & 43.5 & 44.4 & 43.6 & 48.5 & 49.8 \\
\hline Structural activities & 27.6 & 22.5 & 23.5 & 28.5 & 34.2 & 32.8 & 32.4 \\
\hline Specification & 2007 & 2008 & 2009 & 2010 & 2011 & 2012 & 2013 \\
\hline $\begin{array}{l}\text { Sustainable development, including: } \\
\text { competitiveness and cohesion for } \\
\text { growth and employment }\end{array}$ & 43.7 & 45.6 & 44.7 & 48.8 & 54.7 & 61.6 & 71.3 \\
\hline $\begin{array}{l}\text { Natural resources protection and } \\
\text { management }\end{array}$ & 54.6 & 54.8 & 55.9 & 56.6 & 57.4 & 59.1 & 59.5 \\
\hline \multicolumn{4}{|l|}{$\begin{array}{ll}\text { Specification } \\
\end{array}$} & \multicolumn{2}{|c|}{2014} & \multicolumn{2}{|c|}{2015} \\
\hline \multicolumn{4}{|c|}{$\begin{array}{l}\text { Intelligent growth supporting social inclusion, e.g.: competiti- } \\
\text { veness for growth and employment, and social and territorial } \\
\text { economic cohesion }\end{array}$} & \multicolumn{2}{|c|}{67.7} & \multicolumn{2}{|c|}{68.0} \\
\hline \multicolumn{4}{|l|}{ Sustainable growth: natural resources } & \multicolumn{2}{|c|}{56.6} & \multicolumn{2}{|c|}{58.1} \\
\hline
\end{tabular}

Source: the author's own elaboration based on: www.ec.europa.eu/budget/figures/interactive/ index_en.cfm (accessed: 25.01.2017).

Between 2000 and 2006, EU funding was focused on the common agricultural policy, with an average annual budget of around $61 \%$. The pace of changes in the amount of expenditure disbursed in both areas was similar and amounted 
to approx. 3\%. In turn, for most of the period 2007-2013, EU funds were mainly directed towards conservation and management of natural resources. The appropriations accounted for 54\%. It was only in 2012-2013 that higher amounts were earmarked for sustainable economic development. In the whole period, on an average annual basis, they grew at a rate of about $8 \%$. This shows that since 2007, despite the lower amounts spent on sustainable development, their rate of change demonstrated the growing importance of financing this area. This trend continued until 2015, when the money earmarked for smart growth was around 70 billion EUR.

So far, Poland has benefited from three financial perspectives (2004-2006, 2007-2013 and 2014-2020). The country has been the biggest beneficiary of cohesion policy and the Rural Development Programme and the main beneficiary of Direct Subsidies under the Common Agricultural Policy among the new EU Member States. Poland first contributed to the EU budget for a full year in 2005. Its contribution was 2.4 billion EUR (Analiza... 2006). In the following years, the amount rose systematically, and after ten years the contribution has increased by $75 \%$. Since 2004, over 40 billion EUR has been transferred to the EU budget and 146 billion EUR has been returned.

Funds raised by 2016 totalled 130.5 billion EUR, nearly quadrupling the total contributions paid into the EU budget. On a net basis, i.e. after deducting contributions and refunds, the amount obtained was over 87 billion EUR for the entire period.

Over the last dozen years, there has been an increase in transfers from the EU from 2.5 billion EUR in 2004 to over 17 billion EUR in 2014 (without deduction of contributions and returns). Despite this, the EU funds accounted for 1.2\% of GDP in 2004 and 3\% in 2015. Net funding received by Poland from the EU budget, after deduction of contributions and refunds, accounted for $0.57 \%$ in 2004 , while in 2015 it was $2 \%$ of GDP (calculations based on data from: www.stat.gov. pl, www.nbp.pl, www.nik.gov.pl, accessed: 12.07.2017).

In the period 2000-2016 the largest transfer of funds -47 billion EUR over the period, accounting for $36 \%$ of the total gross proceeds - from the EU budget was received for the Structural Funds. The Cohesion Fund was the second largest fund. The funds raised amounted to more than 26 billion EUR (20\%), approximately $19 \%$ of which was allocated for direct payments, while the sum of over 16 billion EUR (12\%) was allocated to the Rural Development Programme. Although the financial perspective for 2014-2020 changed the amount of funds so that they were reduced, this did not negatively impact the amount of funds allocated for Poland. In fact, they increased from 101.5 billion EUR in 2007 to 105.8 billion EUR in 2013. Funds for cohesion policy for Poland increased from 69 billion EUR to 72.9 billion EUR. Finally, the Common Agricultural Policy was allocated 
1.6 billion EUR more (www.msz.gov.pl/pl/polityka_zagraniczna/zagranicznapolityka_ekonomiczna/wieloletnie_ramy_finansowe, accessed: 25.01 .2017$)^{1}$.

Table 2. Financial Flows in 2004-2015 (Billion PLN)*

\begin{tabular}{|c|c|c|c|}
\hline Specification & Transfers from EU & $\begin{array}{c}\text { Membership } \\
\text { Contribution }\end{array}$ & $\begin{array}{c}\text { Balance of Settlements } \\
\text { of Poland with EU }\end{array}$ \\
\hline 2004 & 12.5 & 5.8 & $6.7^{* * *}$ \\
\hline 2005 & 16.1 & 9.9 & 6.2 \\
\hline 2006 & 20.5 & 9.9 & 10.6 \\
\hline 2007 & 28.1 & 10.8 & 17.3 \\
\hline 2008 & 26.9 & 12.2 & 14.7 \\
\hline 2009 & $40.2^{* * * *}$ & 13.4 & 26.7 \\
\hline 2010 & 44.6 & 14.3 & 30.3 \\
\hline 2011 & 58.5 & 14.9 & 43.6 \\
\hline 2012 & 64.6 & 15.9 & 48.7 \\
\hline 2013 & 65.6 & 18.1 & 47.5 \\
\hline 2014 & 71.7 & 17.2 & 54.4 \\
\hline 2015 & 54.6 & 18.2 & 36.4 \\
\hline
\end{tabular}

* According to the average exchange rate of the National Bank of Poland at the end of the year.

** Including the return of funds to the EU budget.

*** The net gain was due to, inter alia, the impact of pre-accession funds and advances for the implementation of programmes co-financed by the Structural Funds.

**** Without funds received under the Financial Mechanisms (Norwegian MF and MFI) and the Swiss-Polish Cooperation Programme.

Source: the author's own study based on: http://www.mf.gov.pl/ministerstwo-finansow/dzialalnosc/ unia-europejska/transfery-finansowe-polska-ue (accessed: 20.12.2017).

According to the new financial framework, the largest part of the allocations comes from cohesion policy, Common Agricultural Policy and Common Fisheries Policy. Additional funds come from programmes managed directly by the European Commission. The Partnership Agreement shows that the total allocation for Poland before transfers was 82.5 billion EUR (at current prices). Mandatory transfers to instruments and programmes managed directly by the European Commission were included, e.g. Fund for European Aid to the most Deprived FEAD), over 475 million EUR (Programming... 2015, p. 158). It is worth noting that the voivodship self-governments will manage a larger amount of EU funds than is currently the case. Between 2007 and 2013, they accounted for 25\% of all funds available to Poland, while in the new perspective it will be almost $40 \%$

\footnotetext{
${ }^{1}$ In order to compare the multiannual financial framework for 2014-2020 with the previous perspective, the results of the negotiations are presented in 2011 constant prices.
} 
(Gospodarcze $i$ społeczne... 2015, p. 10). It can therefore be supposed that this will bring real benefits in the form of better use of EU funds in future perspectives since local authorities better know the needs of local society. Furthermore, new perspectives increase the speed of development of Poland's regions and reduce disparities in GDP per capita between these regions.

Table 2 presents data on the amount of transfers and membership fees converted into national currency.

In 2004-2015, the total amount of funds transferred from the EU to Poland amounted to over 500 billion PLN, of which 160 billion PLN was the fee paid. The decrease in contributions to the European Union budget in 2014 resulted from corrections to the general budget made by the Council and the European Parliament during the financial year (Analiza... 2010, p. 71). As a result, the balance of Poland's settlements with the EU oscillated around 300 billion PLN in the period.

\section{Use of European Funds under Operational Programmes}

The directions of implementation of national public policy are laid out in the National Development Plans that cover the years of the next financial perspectives. Implementation of the National Development Plan is provided by operational programmes financed from national funds or co-financed from community funds (Ustawa z dnia 20 kwietnia 2004 r. ... 2004). The programmes can be national, regional (covering the voivodship) and sectoral. Each programme determines the type of planned projects for which financial support is provided. As in the 20072013 perspective, allocations for 2014-2020 will be based on regional operational programmes implementing national operational programmes. They are intended to support the development of all regions. In this case, the funds are managed not by central authorities, but self-government institutions. Unlike in the previous perspective, regional programmes are dual-fund, meaning that they are financed by the European Regional Development Fund and the European Social Fund. The regional programmes will have a much higher share of the funds allocated to Poland than in previous years. For the first time, voivodships will manage funds under the European Social Fund. With this solution, local governments will have greater autonomy in achieving their development goals.

Reports from the Supreme Chamber of Control show that in the following periods, the following expenses were completed:

1) in the years 2000-2004, 8.4 billion PLN was spent. Funds came from EU pre-accession assistance programmes and other non-recoverable foreign sources, and from 2004 also from the Structural Funds, the Cohesion and the Common 
Agricultural Policy Fund (own calculations, Sprawozdanie... 2001-2016). At the beginning of the implementation of the programmes, the use of funds was very low. NIK data also shows that one of the reasons for the low absorption of Structural Funds involved the complex management and control system, which routinely imposed on individuals the need to carry out tasks not required by community law, and even duplicated some of the actions at subsequent levels of the system (Analiza... 2009, p. 167);

2) between 2005 and 2007, over 53 billion PLN was used. As before, financial resources came from the same sources of funding (Analiza... 2006-2008);

3 ) in the years 2008-2009, projects were implemented for (Analiza ... 2009-2010):

- National Development Plan (NDP) 2004-2006 - 60.8 billion PLN,

- National Strategic Reference Framework (NSRF) 2007-2013 - just over 21 billion PLN,

- Common Agricultural and Fisheries Policy - about 3 billion PLN,

- other non-recoverable funds from the European Union (pre-accession assistance, transitional measures and the Norwegian Financial Mechanism, EEA MF, as well as the Swiss-Polish Cooperation Programme and other sources) 2,3 billion PLN.

Expenditures in this period totalled 87.1 billion PLN.

In the years 2010-2015, the amounts spent were significantly higher, totalling over 385 billion PLN. Table 3 provides detailed data.

In order to implement the assumptions of the European Union policy, much lower amounts were spent from the state budget. In the period under review, the expenditures exceeded just 50 billion PLN. Table 4 presents the data.

The data in Tables 3 and 4 show that expenditures of 435.7 billion PLN were used in 2010-2015, or around 73 billion PLN annually. Less than $12 \%$ of the funds came from the state budget, while $88 \%$ of the expenditure was financed from EU budget funds. At the same time, there was a systematic and gradual increase in financing of expenditure with the funds from the EU budget. Over the period 2014-2015, this funding exceeded $90 \%$ of total expenditure. It should be noted that the actual implementation of income depends on the level of completed expenditure, which is affected by the pace of implementation of individual projects. The level of absorption of funds and the pace of programme implementation depends on many factors, e.g. changes in project implementation schedule and prolonged tendering procedures, which often push projects into the next financial year. As a result, smaller resources launched for the implementation of projects financed under the budget of European funds had an impact on the lower level of expenditure under the budget of the European funds, which in turn translated into lower execution of revenues in relation to the planned budget. 


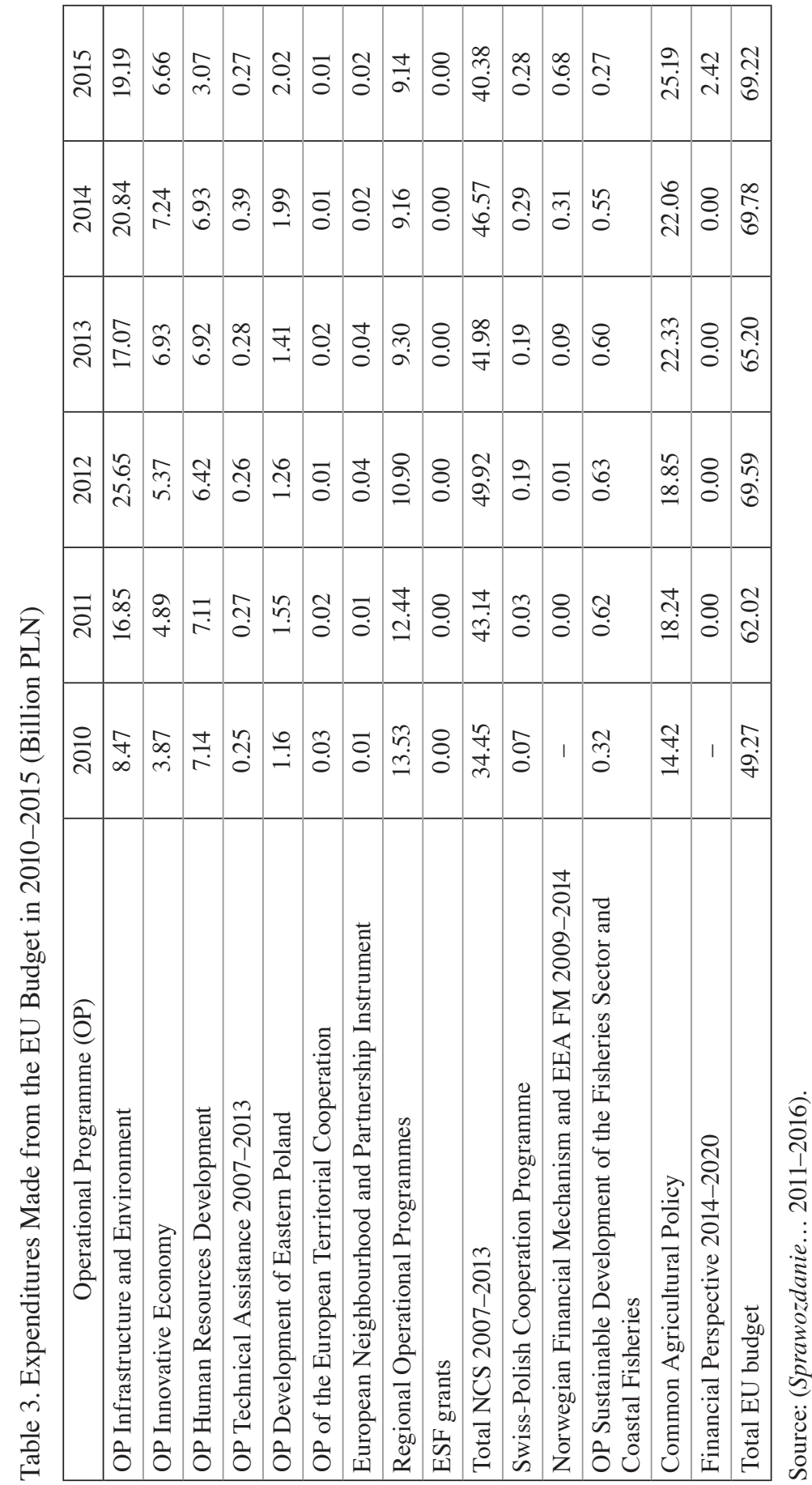




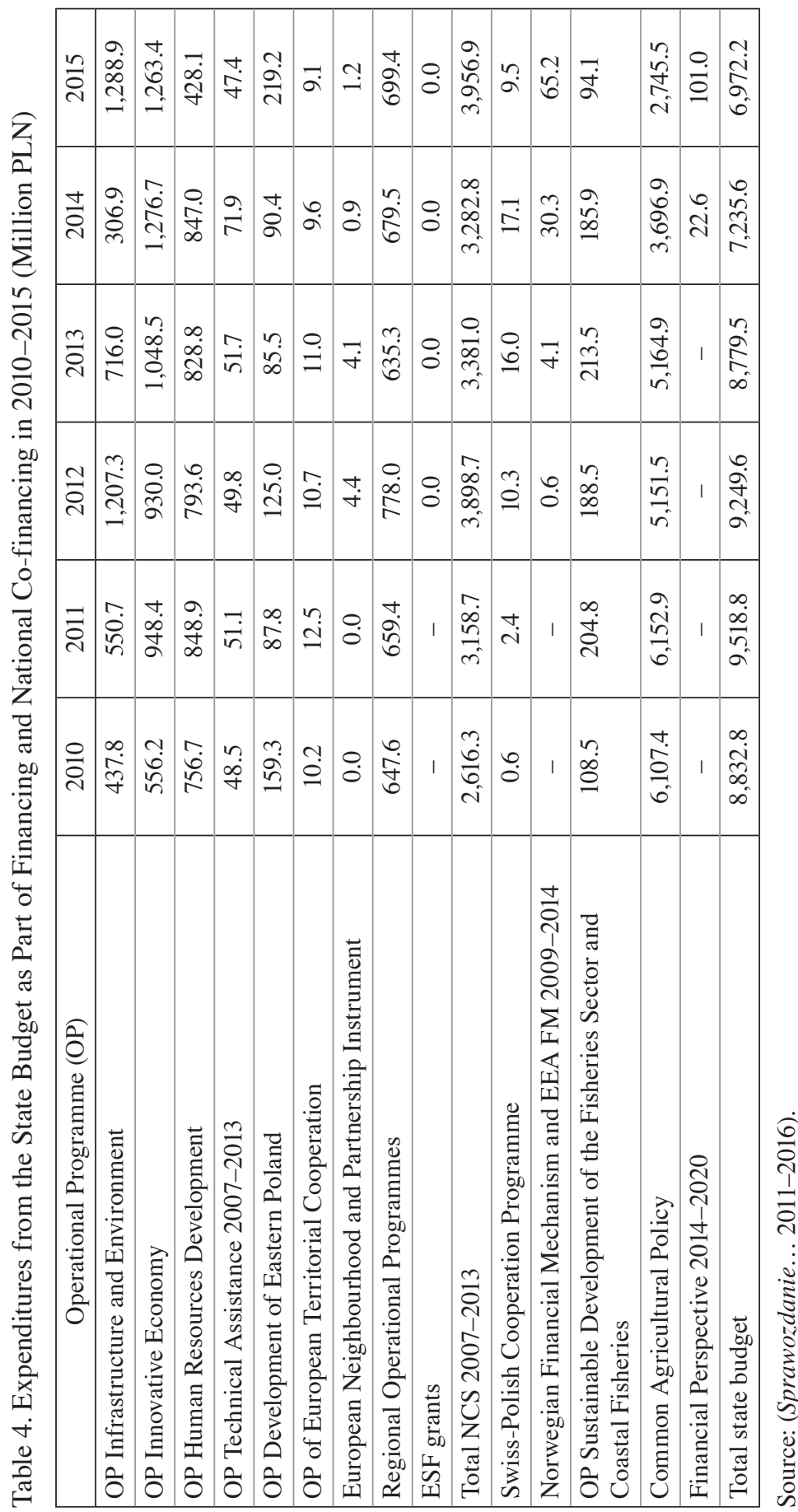




\section{Allocation of Funds by Economic Group Expenditure}

A significant share of expenditure related to the co-financing of EU projects can be noted on the expenditure side of the state budget. National co-financing aims to provide the financial resources needed to implement EU projects. The unit implementing the project requires temporary financing of part of the expenditure. EU funding is provided through reimbursement of part of the expenditure previously made. Table 5 shows state budget expenditure by economic group, including expenditure for co-financing implemented in 2006-2015. The analysis period was shortened accordingly as the first pre-financing expenditure for EU projects from the state budget was incurred in 2006.

The data presented in Table 5 shows that throughout the period, expenditures made from the state budget in the framework of pre-financing and co-financing systematically increased. The share of these expenditures in the overall amount fluctuated on average by around 5\% over the entire period. It 2007-2009, however, this relation increased significantly, and compared to the other years it was considerably higher. Unlike in the past, spending in 2010 with EU funds decreased by 7.2 percentage points from the previous year. This was due to changes resulting from the separation of the state budget of revenue and expenditure and the deficit of EU funds. The name of this pre-financing spending group was also changed into co-financing projects funded by the European Union, as almost all of the financing of expenditure that is reimbursed from the EU was transferred to the budget of European funds. The budget of national funds covered the expenditure on co-financing of projects implemented with European funds, financing of technical assistance projects, projects funded by EFTA member states, and expenditure on projects involving other EU budget funds not included in the budget of European funds (Sprawozdanie... 2010).

The separate treatment of expenditure of "financing of projects involving EU funds" in the group of economic expenditures has made it difficult to figure out, for example, what capital expenses were actually incurred, and the value of grants and subsidies cannot be reliably determined. Due to the differing data layout and their lack of comparability, it is possible to present allocations for co-financing, after inclusion in specific categories of economic expenditure, for the 2008-2012 period alone. Table 6 presents the data.

Expenditure for co-financing projects involving EU funds is the category that actually includes spending belonging to the above groups of economic expenditures. Comparison of expenditures presented in Table 6 with data in Table 5 shows that total expenditure has not changed. Both the cost of servicing the public debt and the contribution to the EU budget have remained unchanged. Other categories have changed. Throughout the period, the amount of grants and 


\begin{tabular}{|c|c|c|c|c|c|c|c|c|c|c|}
\hline$\frac{n}{\tilde{N}}$ & 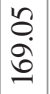 & $\begin{array}{l}n \\
\mathfrak{d} \\
\dot{d} \\
\end{array}$ & $\frac{\vec{\sigma}}{\sigma}$ & 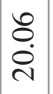 & 1 & ㄱ. & 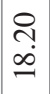 & $\begin{array}{l}\infty \\
\infty \\
\infty\end{array}$ & 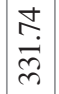 & 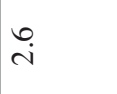 \\
\hline$\frac{\vec{d}}{\stackrel{d}{\circ}}$ & $\begin{array}{c}\text { ஸे } \\
\text { in } \\
\text { ñ }\end{array}$ & $\stackrel{\stackrel{m}{+}}{\stackrel{\sim}{\sim}}$ & $\begin{array}{l}0 \\
0 \\
0\end{array}$ & $\begin{array}{l}n \\
\\
\end{array}$ & 1 & $\begin{array}{l}o \\
\stackrel{+}{+} \\
\dot{m}\end{array}$ & ֻ̊ & $\begin{array}{l}\infty \\
\infty \\
\infty\end{array}$ & $\begin{array}{l}\tilde{n} \\
\stackrel{n}{m}\end{array}$ & $\stackrel{\infty}{i}$ \\
\hline$\stackrel{m}{\tilde{c}}$ & $\begin{array}{l}\text { ำ } \\
\text { ñ } \\
n\end{array}$ & 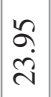 & $\begin{array}{l}\mathcal{Y} \\
\infty \\
\infty \\
\sim\end{array}$ & $\begin{array}{l}\infty \\
\infty \\
\stackrel{\sim}{\sim}\end{array}$ & 1 & 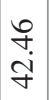 & $\begin{array}{l}\infty \\
\infty \\
\mathcal{I}\end{array}$ & @ొ & $\begin{array}{l}\Re \\
\stackrel{\sim}{\pi}\end{array}$ & ru \\
\hline 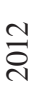 & 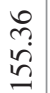 & $\begin{array}{l}8 \\
\ddot{\lambda} \\
\text { ते }\end{array}$ & $\begin{array}{l}\stackrel{\overbrace{}}{\hat{n}} \\
\text { in }\end{array}$ & in & 1 & $\begin{array}{l}\vec{\sim} \\
\underset{f}{*}\end{array}$ & $\begin{array}{l}\Delta \\
\ddot{2} \\
\end{array}$ & $\begin{array}{l}\infty \\
\infty \\
\stackrel{0}{0}\end{array}$ & $\begin{array}{l}8 \\
\stackrel{\infty}{m} \\
\frac{\infty}{m}\end{array}$ & $\stackrel{\oplus}{\oplus}$ \\
\hline$\overline{\vec{\sigma}}$ & 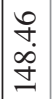 & $\begin{array}{l}\infty \\
\infty \\
\dot{\vec{\lambda}}\end{array}$ & $\begin{array}{l}\tilde{y} \\
m \\
n \\
n\end{array}$ & $\underset{\dot{J}}{\dot{J}}$ & 1 & $\begin{array}{l}\stackrel{\circ}{\circ} \\
\ddot{n} \\
\end{array}$ & 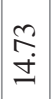 & $\stackrel{\stackrel{q}{*}}{=}$ & $\begin{array}{l}\infty \\
0 \\
i \\
\delta \\
\delta\end{array}$ & $\stackrel{\infty}{\sim}$ \\
\hline $\begin{array}{l}\stackrel{\circ}{\circ} \\
\text { ㄱ. }\end{array}$ & 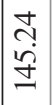 & $\begin{array}{l}\infty \\
\grave{d} \\
\stackrel{\lambda}{0}\end{array}$ & $\begin{array}{l}\bar{\alpha} \\
\hat{n}\end{array}$ & $\begin{array}{l}\text { J } \\
\ddot{n}\end{array}$ & 1 & $\begin{array}{l}\vec{D} \\
\dot{m}\end{array}$ & $\begin{array}{l}\tilde{m} \\
\ddot{z} \\
\dot{y}\end{array}$ & $\stackrel{\sigma}{\sigma}$ & 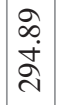 & $\dot{m}$ \\
\hline ஓे & $\begin{array}{l}\varkappa \\
\stackrel{m}{\varrho} \\
=\end{array}$ & $\begin{array}{l}= \\
\vec{i} \\
\dot{i}\end{array}$ & $\frac{\overbrace{}}{\stackrel{n}{n}}$ & $\begin{array}{l}\approx \\
\dot{J} \\
\end{array}$ & 1 & $\begin{array}{l}\underset{\text { }}{\sim} \\
\text { }\end{array}$ & $\begin{array}{l}\stackrel{\sim}{\sim} \\
\stackrel{2}{7}\end{array}$ & $\begin{array}{l}\stackrel{?}{\sim} \\
\stackrel{\sim}{\sim}\end{array}$ & $\begin{array}{l}0 \\
\hat{\infty} \\
\infty \\
\partial \\
\hat{\alpha}\end{array}$ & $\stackrel{\circ}{0}$ \\
\hline 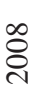 & 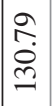 & $\begin{array}{c}\Xi \\
\bar{\lambda}\end{array}$ & $\begin{array}{l}\vec{n} \\
\infty \\
\infty\end{array}$ & $\begin{array}{l}\sigma \\
\dot{J}\end{array}$ & 1 & 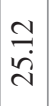 & $\begin{array}{l}\stackrel{\sim}{~} \\
\check{J}\end{array}$ & 굴 & 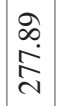 & $\vec{a}$ \\
\hline 효 & $\begin{array}{l}\infty \\
0 \\
\stackrel{\varrho}{=} \\
=\end{array}$ & 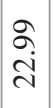 & $\begin{array}{l}\stackrel{9}{+} \\
\stackrel{9}{q}\end{array}$ & $\begin{array}{l}\stackrel{0}{ } \\
\stackrel{n}{2}\end{array}$ & $\stackrel{9}{=}$ & 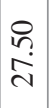 & 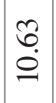 & $\begin{array}{l}\infty \\
\\
\end{array}$ & $\begin{array}{l}\tilde{N} \\
\tilde{\sim} \\
\tilde{n}\end{array}$ & $\stackrel{0}{\circ}$ \\
\hline ঠి & $\begin{array}{c}8 \\
8 \\
\infty \\
0 \\
0\end{array}$ & ડ่ & $\stackrel{\infty}{\stackrel{\infty}{\forall}}$ & $\begin{array}{l}\curvearrowright \\
\infty \\
a\end{array}$ & $\underset{\sigma}{\sigma}$ & $\stackrel{\hat{a}}{\stackrel{N}{N}}$ & $\begin{array}{l}+ \\
\infty \\
\sigma\end{array}$ & $\begin{array}{l}\infty \\
\infty \\
0 \\
0\end{array}$ & 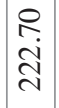 & $\vec{m}$ \\
\hline 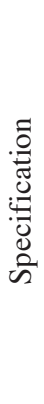 & 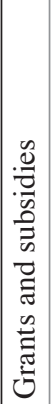 & 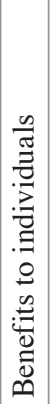 & 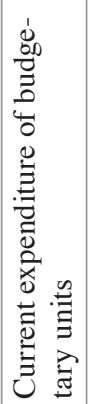 & 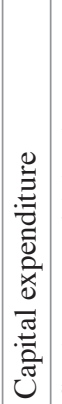 & 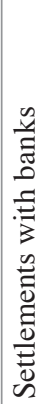 & 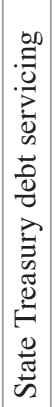 & 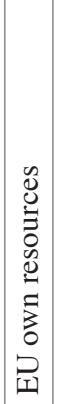 & 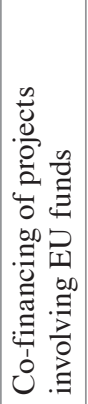 & 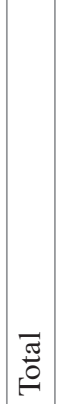 & 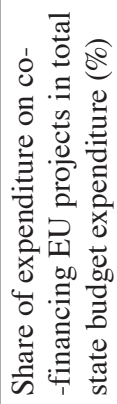 \\
\hline
\end{tabular}


subsidies increased by 61.6 billion PLN (growth of 8.6\%). Subsequently, capital expenditure increased, which in the whole period changed by 24.6 billion PLN (33.4\%). Slight changes can also be observed in the current expenditure categories of budget units. In this case the growth was only 1.7\%. In 2009, expenditure on co-financing increased by $77 \%$. In the same period, expenditure on grants and subsidies increased by only $15 \%$.

Table 6. Expenditure of the State Budget after Inclusion of Expenditure from the Co-financing of Projects Involving EU Funds in 2008-2012 (Billion PLN)

\begin{tabular}{|l|c|c|c|c|c|}
\hline \multicolumn{1}{|c|}{ Specification } & 2008 & 2009 & 2010 & 2011 & 2012 \\
\hline Grants and subsidies & 148.06 & 154.13 & 153.43 & 157.04 & 162.78 \\
\hline Benefits to individuals & 21.17 & 20.11 & 20.89 & 21.88 & 23.00 \\
\hline Current expenditure of budgetary units & 49.44 & 52.19 & 54.85 & 56.27 & 57.97 \\
\hline Capital expenditure & 21.88 & 25.95 & 17.23 & 16.81 & 16.21 \\
\hline State Treasury debt servicing & 25.12 & 32.23 & 34.14 & 35.96 & 42.11 \\
\hline EU own resources & 12.22 & 13.42 & 14.35 & 14.73 & 15.94 \\
\hline Total & 277.89 & 298.03 & 294.89 & 302.68 & 318.00 \\
\hline
\end{tabular}

Source: (Sprawozdanie... 2009-2013).

The great importance of financing from European funds is primarily reflected in the data on the development of economic expenditures from the state budget and the budget of European funds. A detailed account of this is available from 2007 when the EU funds were included in the budget. The implementation of expenditure in particular economic groups is presented, taking into account the expenditure of the co-financing of projects with the participation of European Union funds group. The data is shown in Table 7.

The level of expenditures both from the state budget and from the budget of European funds is high. A comparison of the expenditures presented in Table 7 with data in Table 6 shows just how crucial the financing expenditure from the budget of European funds is. In the period 2010-2012, the average annual expenditures made exclusively from the state budget and allocated for economic purposes classified by economic groups amounted to 305 billion PLN. Expenditures made from the state budget together with the appropriations from the budget of European funds during the same period amounted to 364 billion PLN. In the years 2010-2012, significant expenditure increases were observed in two groups:

- capital expenditure, $181 \%$ on average (expenditure increased by $235 \%$ in 2012),

- grants and subsidies, $18 \%$. 
Table 7. Expenditures by Economic Groups Made from the State Budget and Budget of European Funds in 2010-2015 (Billion PLN)

\begin{tabular}{|l|c|c|c|c|c|c|}
\hline \multicolumn{1}{|c|}{ Specification } & 2010 & 2011 & 2012 & 2013 & 2014 & 2015 \\
\hline Grants and subsidies (for current tasks) & 178.5 & 187.3 & 192.6 & 197.8 & 193.5 & 207.3 \\
\hline Benefits to individuals & 20.9 & 21.9 & 23.0 & 24.0 & 24.4 & 24.7 \\
\hline Current expenditure of budgetary units & 55.4 & 56.8 & 58.5 & 59.9 & 61.4 & 63.4 \\
\hline $\begin{array}{l}\text { Capital expenditure (including grants } \\
\text { and subsidies) }\end{array}$ & 39.7 & 46.8 & 54.2 & 42.9 & 49.9 & 56.8 \\
\hline State treasury debt servicing & 34.1 & 36.0 & 42.1 & 42.5 & 34.5 & 29.2 \\
\hline EU own resources & 14.3 & 14.7 & 15.9 & 18.1 & 17.3 & 18.2 \\
\hline Total & 343.0 & 363.5 & 386.3 & 385.2 & 380.9 & 399.4 \\
\hline
\end{tabular}

Source: (Analiza...2011-2016).

Total expenditures made from the state budget and the budget of European funds increased by $19 \%$. A significant increase in the size and share of capital expenditures in the total expenditure of the state budget and the budget of European funds is the result of the increasing share of European funds in their financing every year. This data confirm that EU funds have significant influence on the structure of public expenditures in Poland. The direction of changes is beneficial: capital expenditures are growing, which is crucial for the country's development.

In 2013, EU funds accounted for more than half of the budget allocated to finance the investment. In 2012, a record-breaking year in this respect, capital expenditure from the budget of European funds amounted to 37,9 billion PLN, more than double the expenditure of the state budget (Analiza... 2012, 2013).

Analysis of state budget expenditure and the budget of European funds shows that these expenditures are predominantly distributed in the form of grants and subsidies for current tasks to other legal entities, both in the public finance sector and in other sectors. The inflow of funds from the EU has significantly increased the importance of capital expenditures, which since 2010 accounted for about 11-12\% of total expenditure. Excluding EU funds, capital expenditure accounts for less than 5\% of total expenditure. As of 2010, the rate of growth of capital expenditure, together with the appropriations from the budget of European funds, has been on average at almost $9 \%$ a year. In the same period, the overall expenditure growth rate was $3 \%$ per annum. The increase in both the size and the share of capital expenditure is due to the increasing share of European funds in their financing, which has been increasing each year since 2008 .

From 2007 to 2013, total grants and subsidies for financing current and investment tasks increased by $76 \%$, while total expenditure was $53 \%$. During the 
period, state budget units spending increased by only 17\% (Sprawozdanie...2013, p. 112). 2012 was the investment peak for the financial perspective 2007-2013. In 2013, more funds were invested in investments than in 2010, when the current investment cycle was advanced. For the first time since Poland's accession to the European Union, the share of capital expenditure financed by European funds in total capital expenditure decreased - from 70,1\% in 2012 to 65,5\% (Analiza... 2013, p. 125).

\section{Conclusion}

The implementation of operational programmes within financial perspectives has benefited Poland financially. The data analysis concerning expenditures according to economic groups confirms the significant impact of EU funds on the level and structure of public expenditure in Poland. However, given the systemic changes made in 2007, 2010 and in 2013, it is difficult to obtain uniform information on the amounts used by Poland for the entire research period (20002016). We therefore needed to focus on certain periods of analysis. In the period 2000-2009, expenditures used from the EU funds amounted to approximately 87 billion PLN. While in the years 2010-2015, the budget of the European funds financed the implementation of programmes totalling over 385 billion PLN.

In addition to the financial benefits presented, it is important to bear in mind that the EU funding policy or co-financing of EU projects is both encouraging and motivating for undertaking the new initiatives, both public and private. Changes in the level of capital expenditures prove this.

Over the long term, however, it is important what goals will be achieved with these funds. The countries of Central and Eastern Europe largely allocate these funds for road and rail infrastructure. It is also important to focus on research and development, which will support the economy's long-term development.

\section{Bibliography}

Analiza wykonania budżetu państwa i założeń polityki pienię̇̇nej [The analysis of the state budget implementation and monetary policy assumptions] (2006-2016), Najwyższa Izba Kontroli, Warszawa.

Czepiel A. P. (2016), Pora zaczać mierzyć wpływ funduszy unijnych na gospodarkę [It is time to measure the impact of EU funds on the economy], www.obserwatorfinansowy.pl/forma/rotator/pora-zaczac-mierzyc-wplyw-funduszy-unijnych-na-gospodarke/ (accessed: 22.11.2017).

Gospodarcze i społeczne efekty członkostwa Polski w Unii Europejskiej. Notatka w zwiazku z jedenasta rocznica przystapienia Polski do UE [The economic and social effects of 
Poland's membership in the European Union. Note in connection with the eleventh anniversary of Poland's accession to the EU] (2015), www.msz.gov.pl/resource/26c005f4b73e-4402-bb32-8b10c1b42a4c:JCR (accessed: 25.01.2017).

Kasperowicz-Stępień A. (2011), Kształtowanie się wydatków publicznych w Polsce w latach 2005-2009 [Formulation of public expenditure in Poland in 2005-2009], "Zeszyty Naukowe Polskiego Towarzystwa Ekonomicznego", no 10.

Klimowicz M. (2010), Fundusze strukturalne oraz Fundusz Spójności w państwach Europy Środkowej $i$ Wschodniej [Structural funds and Cohesion Fund in the countries of Central and Eastern Europe], CeDeWu, Warszawa.

Mandl U., Dierx A., Ilzkovitz F. (2008), The Effectiveness and Efficiency of Public Spending, Economic Papers 301, European Commission, Brussels.

Moździerz A. (2009), Nierównowaga finansów publicznych [Imbalance of public finances], PWE, Warszawa.

Multiannual Financial Framework 2014-2020 and EU Budget 2014. The Figures (2013), European Commission, Brussels.

Owsiak S. (2017), Finanse publiczne. Teoria i praktyka [Public finance. Theory and practice], Wydawnictwo Naukowe PWN, Warszawa.

Podlińska O., Gołębiewski J. (2013), Wpływ środków unijnych na wydatki inwestycyjne jednostek samorzadu terytorialnego [Influence of the European Union funds onto the investment expenditure of the self-government units], "Roczniki Naukowe Stowarzyszenia Ekonomistów Rolnictwa i Agrobiznesu”, vol. 15, no 5.

Polska w Unii Europejskiej [Poland in the European Union] (2016), Komunikat z Badań CBOS no 31/2016, CBOS, Warszawa.

Programming of the 2014-2020 Financial Perspective. Partnership Agreement (2014), Ministry of Infrastructure and Development, Warsaw.

Sprawozdanie z wykonania budżetu państwa, sprawozdania za lata 2000-2015 [Report on implementation of the state budget, for the years 2000-2015] (2001-2016), Ministerstwo Finansów, Warszawa.

Sawulski J. (2016), Finanse publiczne w Polsce - diagnoza na tle innych krajów [Public finance in Poland - diagnosis on the bacground other countries], IBS Policy Paper 04/2016, IBS, Warszawa.

Sosińska-Wit M. (2014), Ocena wykorzystania funduszy unijnych w małych i średnich przedsiębiorstwach województwa lubelskiego [Assessment of using EU funds in small and medium enterprises in Lubelskie Voivodship], "Economics and Management", no 3, https://doi.org/10.12846/j.em.2014.03.11.

Tomova M., Rezessy A., Lenkowski A., Maincent E. (2013), EU Governance and EU funds - Testing the Effectiveness of EU Funds in a Sound Macroeconomic Framework, Economic Papers 510, European Commission, Brussels.

Ustawa z dnia 20 kwietnia 2004 r. o Narodowym Planie Rozwoju [The Act of 20 April 2004 on the National Development Plan], Dz.U. No 116, item 1206, as amended.

Wostner P., Šlander S. (2009), The Effectiveness of EU Cohesion Policy Revisited: Are EU Funds Really Additional? European Policy Research Paper 69, EPRC, Glasgow. 


\section{Wpływ funduszy europejskich na wydatki publiczne w Polsce} (Streszczenie)

Celem opracowania było dokonanie oceny wpływu środków funduszy europejskich na wysokość i strukturę wydatków publicznych w Polsce. Okres badawczy obejmował lata 2000-2016. Postawiona została następująca hipoteza: środki finansowe pochodzące z funduszy Unii Europejskiej mają istotny wpływ na wysokość i strukturę wydatków publicznych.

Przeprowadzona analiza danych dowiodła, że udział środków z Unii Europejskiej w finansowaniu zadań publicznych jest wysoki, a struktura wydatków publicznych uległa istotnej zmianie. W okresie 2010-2015 środki te stanowiły ok. 88\% wydatków publicznych. Zauważyć można także ich systematyczny i stopniowy wzrost. W latach 2014-2015 finansowanie to przekroczyło 90\% ogółu zrealizowanych wydatków.

Słowa kluczowe: fundusze europejskie, programy operacyjne, budżet środków UE, wydatki publiczne. 